\title{
Eco Stoichiometric Characteristics of Soil Plant System of Taxus wallichiana under Multi Factor Driving
}

\author{
Jiachun Zhang ${ }^{1}$, Xianliang $\mathrm{Wu}^{2}$, Zhenming Zhang ${ }^{2 *}$, Xianfei Huang ${ }^{3}$, Guiting $\mathbf{M u}^{1}$ \\ ${ }^{1}$ Guizhou Botanical Garden, Guizhou Academy of Sciences, Guiyang, Guizhou 550000, P. R. China \\ ${ }^{2}$ Institute for Forest Resources \& Environment of Guizhou, Key Laboratory of Forest Cultivation in Plateaumountain \\ Area, College of Forestry, Guizhou University, Guiyang 550025, China \\ ${ }^{3}$ Guizhou Provincial Key Laboratory for Environment, Guizhou Normal University, Guiyang, 550001 P. R. China
}

Received: 20 October 2020

Accepted: 10 April 2021

\begin{abstract}
To investigate the soil fertility of the rare plant, Taxus wallichiana var. mairei, the distribution characteristics and corresponding influencing factors of carbon $(\mathrm{C})$, nitrogen $(\mathrm{N})$, and phosphorus $(\mathrm{P})$ in Taxus wallichiana and its surrounding soil were determined in this study. Redundancy analysis was used to evaluate the relationship among different indicators of soil surrounding Taxus wallichiana trees. The results exhibited that the contents of organic matters, Total-N, Total-P, Hydrolyzable-N, and Valid-P in soils surrounding the Taxus wallichiana trees was $44.24 \pm 5.04 \mathrm{~g} / \mathrm{kg}, 3.81 \pm 0.53 \mathrm{~g} / \mathrm{kg}, 2.02 \pm 2.80 \mathrm{~g} / \mathrm{kg}$, $679.73 \pm 27.61 \mathrm{mg} / \mathrm{kg}$ and $248.95 \pm 45.15 \mathrm{mg} / \mathrm{kg}$, respectively. The contents of $\mathrm{C}, \mathrm{N}$ and $\mathrm{P}$ in Taxus wallichiana leaves was $46.03 \pm 1.10 \%, 1.89 \pm 0.43 \%$ and $11.49 \pm 3.32 \%$, respectively; and in Taxus wallichiana stem was $45.83 \pm 0.33 \%, 0.71 \pm 0.19 \%$ and $9.96 \pm 3.10 \%$, respectively. Concerned nutrients in the soils surrounding Taxus wallichiana trees were abundant. The soil fertility index was 4.94 according to the improved Nemerow index method with the weighted average, which suggested that the soil surrounding Taxus wallichiana trees was fertile in Mount Fanjing. The contents of C, N and $\mathrm{P}$ in the leaf of Taxus wallichiana were greater than that in its stems. The soil $\mathrm{C}$ was the major factor impacting the distribution of $\mathrm{N}$ in the stem of Taxus wallichiana. The soil vaild-P was the critical factor influencing the distribution of $\mathrm{P}$ in the stem of Taxus wallichiana. The soil bulk density was the highest influencing factor of the $\mathrm{C}$ content in the leaf of Taxus wallichiana. The total-P in the soil has the dominant governance on the $\mathrm{P}$ content in the plant.
\end{abstract}

Keywords: indicators of soil, Nemerow index, redundant analysis, Taxus wallichiana var. maire, driving factors

*e-mail: zhangzm@gzu.edu.cn 


\section{Introduction}

A certain stoichiometric relationship could be witnessed among a plurality of elements in the ecosystem and its components, which is homeostasis that maintains the growth of an individual, or even the structure, function, and stability of the ecosystem [1]. Carbon (C), nitrogen (N), and phosphorus (P) in plants are the basic nutrient elements required by plants; meanwhile, these elements are important for cell metabolism, protein and genetic materials [2]. The stoichiometry of elements is a hotspot in the current research on ecological field, which is aim to probe into the important role of physiological and biochemical processes of $\mathrm{C}, \mathrm{N}, \mathrm{P}$ and other elements in the biogeochemical cycle and energy sources [3-5]. As one of the universal characteristics of the measurement of $\mathrm{C}, \mathrm{N}$ and $\mathrm{P}$ in high terrestrial plants, it is reported that the significant negative correlation of the leaf $\mathrm{C}$ and $\mathrm{N}$ : $\mathrm{P}$ is an equilibrium strategy for nutrient use efficiency of green plants during the fixed carbon process [68]. Besides, the dynamic equilibrium between soil nutrient supply and plant nutrient requirements can be exhibited in $\mathrm{C}, \mathrm{N}$, and $\mathrm{P}$ contents of plants [911]. Moreover, it is demonstrated that plants under different growth environments can develop their own physical mechanisms for acclimatization, disclosing survival strategies of plants, on the basis of studying stoichiometric characteristics of $\mathrm{C}, \mathrm{N}$, and $\mathrm{P}$ in roots, stems and leaves of terrestrial plants [12-14].

Taxus wallichiana var. mairei is one of the unique components of China's subtropical-warm temperate zone, and also a representative rare tree species of Mount Fanjing in Guizhou, which has been studied since 1970s [15]. It was endangered because of several characteristics (e.g. narrow distribution range, small quantity and poor capacity for natural regeneration, etc.), it has been listed as the national first-class protective plant [16]. Despite the protection of Taxus wallichiana has been gradually enriched and improved with the attention of relative department, some information are still unclear [17]. Previously, researches on Taxus wallichiana was primarily focused on morphology and characteristics of community environment, geographical distribution, breeding biology, and conservation genetics [18]. Rare study concernsthe distribution characteristics of $\mathrm{C}, \mathrm{N}$, and $\mathrm{P}$ in Taxus wallichiana and protects the rare plants using the stoichiometric ratio of $\mathrm{C}, \mathrm{N}$, and $\mathrm{P}$. Therefore, the contents of $\mathrm{C}, \mathrm{N}$, and $\mathrm{P}$ in the rare plant (Taxus wallichiana) were determined to reveal the distribution of $\mathrm{C}, \mathrm{N}$, and $\mathrm{P}$. Meanwhile, and the use efficiency of nutrient Taxus wallichiana was also investigatedaccording to $\mathrm{C}: \mathrm{N}, \mathrm{C}: \mathrm{P}$, and $\mathrm{N}$ : $\mathrm{P}$ after systematically studying its soil fertility [19]. These works can provide theoretic supports for protecting Taxus wallichiana in Mount Fanjing and increase the number of Taxus wallichiana. Simultaneously, the efforts will ensure the sustainable and stable development of Taxus wallichiana, and stabilize the biodiversity of rare plants in China with scientific and effective methods.

\section{Methods and Materials}

\section{Overview of the Study Area}

Mount Fanjing is selected in this study, which is located at the junction of Jiangkou, Songtao, and Yinjiang counties in the northeast of Guizhou. The coordinate of this studyis ranged from $108^{\circ} 45^{\prime} 55^{\prime \prime}$ to $108^{\circ} 48^{\prime} 30^{\prime \prime}$, and the north latitude ranged from $27^{\circ} 49^{\prime} 50^{\prime \prime}$ to $28^{\circ} 1^{\prime} 30^{\prime \prime}$. The experimental materials were collected from core areas of Mount Fanjing. The core area covers 24,600 hectares, accounting for $58.7 \%$ of the total area. Mount Fanjing belongs to East Asian monsoon climate zone with an average annual temperature ranging from $5^{\circ} \mathrm{C}$ to $17^{\circ} \mathrm{C}$ and an annual precipitation ranging from $1100 \mathrm{~mm}$ to $2600 \mathrm{~mm}$, which is a region with the most precipitation in Guizhou. With an annual relative humidity above $80^{\circ} \mathrm{C}$, Mount Fanjing has typical humid climate characteristics of the mid-subtropical monsoon mountain areas [20].

\section{Sample Collection}

Soil and plant samples were collected from Lanchading (108 $\left.42^{\prime} 29^{\prime \prime} \mathrm{E}, 27^{\circ} 55^{\prime} 59^{\prime \prime} \mathrm{N}\right)$ at an elevation of $2000 \mathrm{~m}$ (October, 2019). Eighteen sampling points were designed according to representative positions (Fig. 1). At each sampling points, plant stems and leaves were collected, packed, and marked separately. Soils were collected in the north, east, south and west aspects of Taxus wallichiana tree ( $2 \mathrm{~m}$ away from the base of trunk), and the mixed soil was obtained as final soil sample [21].

\section{Sample Treatment and Determination}

To determine $\mathrm{C}, \mathrm{N}$, and $\mathrm{P}$ contents in the soil, soil samples collected were dried and successively removed impurities, such as gravels, plant root and leaf fragments. The treated soil was ground and sifted through a 100-mesh sieve. Plants were dusted with pure water before being dried in an oven at $65^{\circ} \mathrm{C}$. The handled plant was pulverized with a pulverizer and sifted through a 60-mesh sieve for determining $\mathrm{C}, \mathrm{N}$, and $\mathrm{P}$ contents in the plant. The content of carbon in soil and plant was determined by the $\mathrm{K}_{2} \mathrm{Cr}_{2} \mathrm{O}_{7}-\mathrm{H}_{2} \mathrm{SO}_{4}$ oil bath outside heating method. The contents of total-N and total-P of carbon in soil and plant were measured using the Kjeldahl distillation method and the molybdenum antimony colorimetric method, respectively. The available phosphorus was extracted by double acid $\left(\mathrm{HCl}-\mathrm{H}_{2} \mathrm{SO}_{4}\right)$ and determined by molybdenum antimony resistance colorimetry. The available potassium was extracted by ammonium acetate and flame photometric method. The basic diffusion method was used to 


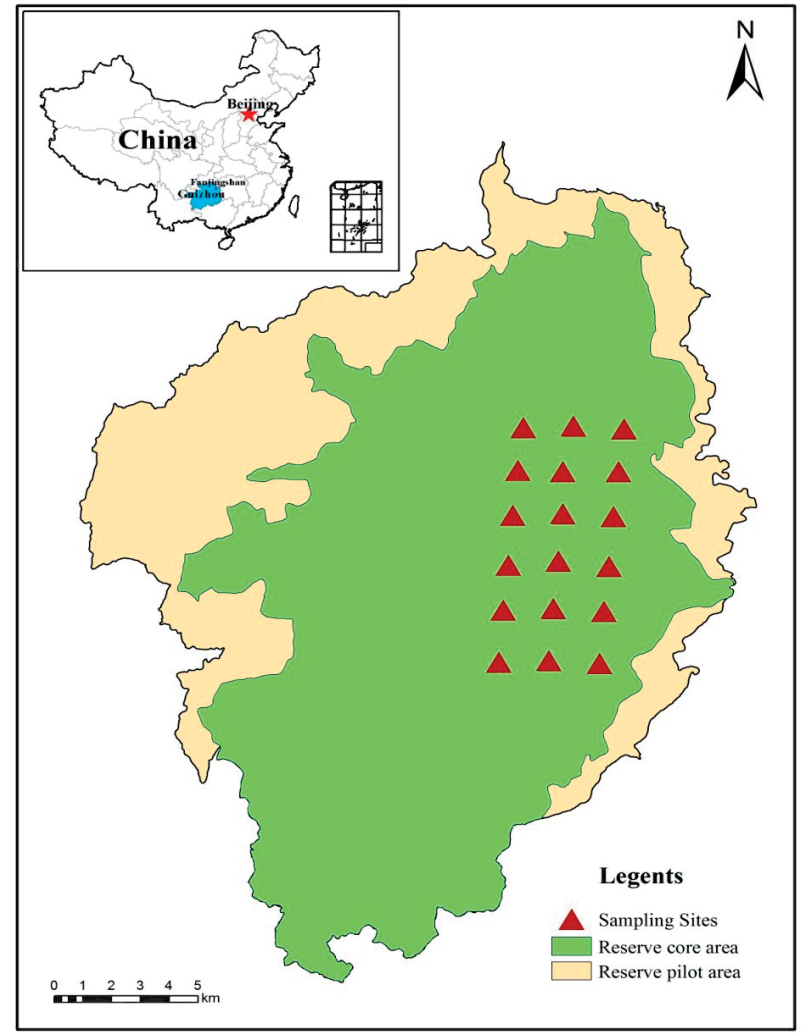

Fig. 1. Location and sampling points of the study area.

hydrolyze nitrogen. The metal contents of soil were digested with $\mathrm{HNO}_{3}-\mathrm{HF}$ microwaves and determined with ICP-OES (prodigy $\mathrm{xp}$ ). The recovery rates of physical and chemical indicators of various soils were within the allowable ranges. The soil nutrient classification standard was formulated by referring to the $2^{\text {nd }}$ national soil survey (Table 1 ).

\section{Calculation of Soil Dertility Indexes with the Improved Nemerow Index Method}

Soil fertility is a comprehensive reflection of the supply ability of soil nutrients for specific plants and the environmental conditions. Soil nutrients, plants, and environmental conditions together make up the extension of soil fertility. Soil fertility depends on the separate effects of various factors, i.e. soil nutrients, the absorptive capacity of plants, and environmental conditions of plant growth. Meanwhile, it also was decided by the harmonization of various factors. Since the single index (attribute value) of soil fertility cannot be adducted, data should be standardized to unify the dimension and eliminate dimensional differences between various indexes. The common standardization approaches have been widely employed, e.g. standard deviation, range standardization, mean standardization, and standardization of initial value. These methods are not applicable in this study due to the weak comparability. In this work, the following improved method was adopted [22].

$$
q_{i}=\left\{\begin{array}{cc}
c_{i} / c_{x} & c_{i} \leq x_{a} \\
1+\left(c_{i}-x_{a}\right) /\left(x_{c}-x_{a}\right) & x_{a}<c_{i} \leq x_{c} \\
2+\left(c_{i}-x_{c}\right) /\left(x_{p}-x_{c}\right) & x_{c}<c_{i} \leq x_{p} \\
3 & c_{i} \geq x_{p}
\end{array}\right.
$$

...where, $q_{i}$ is called the sub-fertility coefficient; $c_{i}$ is the measured value. The grading standard $\left(x_{a}, x_{c}\right.$, and $x_{p}$ ) of the actual values refer to the $2^{\text {nd }}$ national soil survey standard, as shown in Table 2. An excellent comparability can be witnessed in individual soil fertility coefficients obtained by the standardization of the calculation method. Moreover, the sub-fertility coefficient stops increasing and becomes constant at 3 after the measured value of an attribute exceeds the fertility coefficient of a certain standard. The situation exhibits that certain attributes have saturation values rather than the higher the better in the process of plant growth. Simultaneously, the rationality of soil fertility coefficient can be guaranteed by scientifically mastering and controlling the saturation point.

Because of the different contribution of various soil fertility factors, a certain weight should be given to each index. Nevertheless, it is critical for how to determine the weight coefficient of a fertility index in the comprehensive evaluation of fertility. In previous studies, several methods were commonly used to determine the weight coefficient, viz. artificialscoring, factor analysis, cluster analysis, grey relational analysis, factor weighted synthetic, and variation coefficient

Table 1. Classification standards for the second national soil census.

\begin{tabular}{|c|c|c|c|c|c|c|}
\hline Index & I & II & III & I & II & III \\
\hline Total-N $(\mathrm{g} / \mathrm{kg})$ & $>2$ & $1.5 \sim 2$ & $1 \sim 1.5$ & $0.75 \sim 1$ & $0.5 \sim 0.75$ & $<0.5$ \\
\hline Total-P $(\mathrm{g} / \mathrm{kg})$ & $>1$ & $0.8 \sim 1$ & $0.6 \sim 0.8$ & $0.4 \sim 0.6$ & $0.2 \sim 0.4$ & $<0.2$ \\
\hline Hydrolyzable-N $(\mathrm{mg} / \mathrm{kg})$ & $>150$ & $120 \sim 150$ & $90 \sim 120$ & $60 \sim 90$ & $30 \sim 60$ & $<30$ \\
\hline Valid-P $(\mathrm{mg} / \mathrm{kg})$ & $>40$ & $20 \sim 40$ & $10 \sim 20$ & $5 \sim 10$ & $3 \sim 5$ & $<3$ \\
\hline Organic matters $(\mathrm{g} / \mathrm{kg})$ & $>40$ & $30 \sim 40$ & $20 \sim 30$ & $10 \sim 20$ & $6 \sim 10$ & $<6$ \\
\hline Level description & Very high & High & Above the average & Below the average & Low & Very low \\
\hline
\end{tabular}


Table 2. Revised limit of soil nutrient content.

\begin{tabular}{|c|c|c|c|c|c|}
\hline Project & Total-N $(\mathrm{g} / \mathrm{kg})$ & Total-P $(\mathrm{g} / \mathrm{kg})$ & Valid-P $(\mathrm{mg} / \mathrm{kg}))$ & Hydrolyzable-N $(\mathrm{mg} / \mathrm{kg})$ & Organic matters $(\mathrm{g} / \mathrm{kg})$ \\
\hline$x_{a}$ & 0.75 & 0.7 & 5 & 60 & 10 \\
\hline$x_{c}$ & 1 & 1.5 & 10 & 90 & 20 \\
\hline$x_{p}$ & 1.5 & 2 & 20 & 150 & 30 \\
\hline
\end{tabular}

methods. In this study, the method of weighted mean was employed to avoid subjective influence.

The method of weighted mean is to calculate weights with the ratio of the measured content of the evaluation factor in the soil environment to its corresponding grading standard. The method could reflect the influence of evaluation factors on the degree of pollution to a certain extent. The formula is presented as follows:

$$
W_{\mathrm{i}}=\frac{c_{i} / \mathrm{S}_{\mathrm{i}}}{\sum_{\mathrm{i}=1}^{\mathrm{n}} c_{i} / \mathrm{S}_{\mathrm{i}}}
$$

...where, $W_{i}$ is the weight of the $i_{\text {th }}$ factor. The $n$ is the number of factors participating in evaluation. $x_{i}$ is the measured value of the factor participating in evaluation. $S_{i}$ is the mean value of the sum of the grading standard of each attribute of each soil corresponding to the $i_{\text {th }}$ factor, viz. $S i=\left(x_{a}+x_{c}+x_{p}\right) / 3$. Each single index can be used for analyzing soil fertility, whereas the single index is onesided and unpersuasive in evaluating the overall status of soil fertility. Hence, the improved Nemerow index method was introduced in this study for comprehensive evaluation. The comprehensive soil fertility coefficient was calculated with the improved Nemerow formula to reflect factors limiting plant growth. The level of soil fertility can be comprehensively and simply reflected in quantification by the improved Nemerow comprehensive index method. The formula of modified Nemerow is shown as follows:

$$
\begin{gathered}
P_{i}=q_{i} \times W_{i} \times n \\
P=\sqrt{\frac{\left(P_{\mathrm{i} \text { aver }}\right)^{2}+\left(P_{\text {imin }}\right)^{2}}{2} \times \frac{(n-1)}{n}}
\end{gathered}
$$

...where $P$ is the comprehensive soil fertility index. $P_{\text {iaver }}$ is the mean value of the sub-fertility coefficient of attributes of the soil. $P_{\text {imin }}$ is the minimum value of each sub-fertility coefficient. $W_{\mathrm{i}}$ is the weighted value. The $n$ is the number of factors participating in evaluation. Substituting $P_{\text {imin }}$ for $P_{\text {imax }}$ in the original Nemerow formula is to highlight the influence of the worst index of soil attributes on fertility, or to highlight the limiting factors. The correction term $(n-1) / n$ is to reflect credibility. The higher soil attributes $(n)$ involving in the evaluation project is, the higher the credibility is. Soil fertility grading standards are presented in Table 3.

\section{Statistical Analysis of Data}

Characteristics of stoichiometric numbers of $\mathrm{C}$ and $\mathrm{N}$ and $\mathrm{P}$ in the soil and plant were compared with the T-test. The relationship between $\mathrm{C}, \mathrm{N}$ and $\mathrm{P}$ contents in the plant and soil nutrients was determined using the coefficient method relating to SPSS Statistics 19.0 pearson.

\section{Results and Analysis}

\section{Characteristics of C, N and P Contents in the Soil and Plant of Taxus wallichiana}

The growth of Taxus wallichiana is subjected to the manifold influence of external environment and internal environment. It is extremely important to know the content of $\mathrm{C}, \mathrm{N}$ and $\mathrm{P}$ in the soil and the $\mathrm{C}, \mathrm{N}$ and $\mathrm{P}$ are essential elements for plant growth. Table 4 demonstrates the significant differences in $\mathrm{C}$, $\mathrm{N}$, and $\mathrm{P}$ contents in the soil of Taxus wallichiana in Mount Fanjing. Additionally, to quantitatively reflect fluctuations in contents of various indicators in the survey area, the coefficient of variation was utilized to reveal the magnitude of variation. Specifically, the variations in various nutrient elements of Taxus wallichiana were ranged from $4.06 \%$ to $138.61 \%$. In particular, the coefficient of variation in Total-P is in excess of $100 \%$. Notablely, the enrichment of total-P is varied remarkably at different locations, which is closely associated with the uneven distribution of Taxus wallichiana in Mount Fanjing.

Table 3. Soil fertility classification.

\begin{tabular}{|c|c|c|c|c|}
\hline Very fertile & Fertile & Common & Impoverishment & Especial impoverishment \\
\hline$P \geq 2.12$ & $1.42<P<2.12$ & $0.72<P<1.42$ & $0.47<P<0.72$ & $P \leq 0.47$ \\
\hline
\end{tabular}


Table 4. Means and standard deviation of nutrients and $\mathrm{C} / \mathrm{N}$ in soils surrounding the Taxus chinensis trees.

\begin{tabular}{|c|c|c|c|c|c|}
\hline Item & $\begin{array}{c}\text { Organic matters } \\
(\mathrm{g} / \mathrm{kg})\end{array}$ & $\begin{array}{c}\text { Total-N } \\
(\mathrm{g} / \mathrm{kg})\end{array}$ & $\begin{array}{c}\text { Total-P } \\
(\mathrm{g} / \mathrm{kg})\end{array}$ & $\begin{array}{c}\text { Hydrolyzable-N } \\
(\mathrm{mg} / \mathrm{kg})\end{array}$ & $\begin{array}{c}\text { Valid-P } \\
(\mathrm{mg} / \mathrm{kg})\end{array}$ \\
\hline Average Value \pm Standard Deviation & $44.24 \pm 5.04 \mathrm{~b}$ & $3.81 \pm 0.53 \mathrm{~b}$ & $2.02 \pm 2.80 \mathrm{a}$ & $679.73 \pm 27.61 \mathrm{~b}$ & $248.95 \pm 45.15 \mathrm{c}$ \\
\hline Coefficient of variation $(\%)$ & 19.64 & 13.91 & 138.61 & 4.06 & 18.14 \\
\hline
\end{tabular}

Note: Means and standard errors. Within rows, the values followed by the same lowercase letter $(\mathrm{a}-\mathrm{c})$ are not significantly different $(\mathrm{p}<0.05)$ for the same soil layer among different indexes; the significance was determined by Analysis of Variance (ANOVA).

$\mathrm{C}, \mathrm{N}$ and $\mathrm{P}$ are major nutrients required for plant growth and they play an essential role in plant growth. Table 5 showed that the differences of $\mathrm{N}$ and $\mathrm{P}$ contents in stems and leaves are obvious, whereas the difference of $\mathrm{C}$ contents in stems and leaves is insignificant. The contents of $\mathrm{C}, \mathrm{N}$ and $\mathrm{P}$ of Taxus wallichiana are presented as leaf $>$ stem $(46.03 \%>45.83 \%, \quad 1.89 \%>$ $0.72 \%$ and $11.49 \%>9.96 \%$ ). The coefficient of variation of Taxus wallichiana leaves is ranged from $0.72 \%$ to $8.42 \%$ with uniform distribution, indicating that it is less affected by the outside environment. The coefficient of variation of $\mathrm{N}$ and $\mathrm{P}$ in plant stems and leaves is ranged from $12.82 \%$ to $31.12 \%$, presenting the moderate variation.

The stoichiometric ratio of $\mathrm{C}: \mathrm{N}$ : $\mathrm{P}$ in soil reflects soil fertility and the nutritional status of plants. The growth and distribution of plant is affected by the coupling changes between elements. C: N, C: P and N: $\mathrm{P}$ in soil were $11.61 \pm 1.12,21.90 \pm 2.12$, and $1.89 \pm 0.51$, respectively. The coefficient of variation of $\mathrm{N}$ : $\mathrm{P}$ in soil was the highest. By comparison, the stoichiometric ratio of $\mathrm{C}$ : $\mathrm{N}$ : $\mathrm{P}$ in the leaf of Taxus wallichiana has little influence with a similar rule of the variation coefficient. $\mathrm{C}$ : $\mathrm{N}$ in the stem of Taxus wallichiana reaches up to $68.38 \pm 19.08$ with a large coefficient of variation. In contrast, the $\mathrm{C}$ : $\mathrm{N}$ coefficient of variation in the leaf of Taxus wallichiana is small (as shown in Table 6).

\section{Characteristics of Soil Fertility in the Soil of Taxus wallichiana}

Varied soil fertility factors can be calculated using the different approaches according to the weighted calculation result of single-factor index of soil fertility. We found the valid-P is an important factor when the weight of the soil fertility index in the study area is studied by the method of weighted average, which can significantly affect the soil fertility in the area. The weighted value after calculating with the weighted average method is presented in Fig. 2. Before weighting, the soil fertility index in the study area was 14.75 , which was classed as the very fertile level in combined with Table 7. By weighting the improved Nemerow index method with the weighted average, the soil fertility index in the study area is 4.94, indicating the very fertile soil in this study area. It is apparent that there are huge differences between the two methods.

Table 5. Content characteristics of C, N and P in Taxus chinensis trees.

\begin{tabular}{|c|c|c|c|c|}
\hline Vegetations & Item & C (\%) & N (\%) & P (\%) \\
\hline \multirow{2}{*}{ Taxus chinensis - leaves } & Average Value \pm Standard Deviation & $46.03 \pm 1.10 \mathrm{~cd}$ & $1.89 \pm 0.43 \mathrm{~d}$ & $11.49 \pm 3.32 \mathrm{~b}$ \\
\cline { 2 - 5 } & Coefficient of variation (\%) & 2.39 & 22.75 & 28.89 \\
\hline \multirow{2}{*}{ Taxus chinensis - stem } & Average Value \pm Standard Deviation & $45.83 \pm 0.33 \mathrm{c}$ & $0.71 \pm 0.19 \mathrm{a}$ & $9.96 \pm 3.10 \mathrm{~b}$ \\
\cline { 2 - 5 } & Coefficient of variation $(\%)$ & 0.72 & 26.76 & 31.12 \\
\hline
\end{tabular}

Table 6. Content characteristics of C:N, C:P and N:P in Taxus chinensis.

\begin{tabular}{|c|c|c|c|c|}
\hline Project & Item & C/N & C/P & N/P \\
\hline \multirow{2}{*}{ Taxus chinensis-soils } & Average Value \pm Standard Deviation & $11.61 \pm 1.12 \mathrm{~b}$ & $21.90 \pm 2.12 \mathrm{a}$ & $1.89 \pm 0.51 \mathrm{~b}$ \\
\cline { 2 - 5 } & Coefficient of variation (\%) & 9.65 & 9.68 & 26.98 \\
\hline \multirow{2}{*}{$\begin{array}{c}\text { Taxus chinensis- } \\
\text { leaves }\end{array}$} & Average Value \pm Standard Deviation & $25.35 \pm 5.14 \mathrm{a}$ & $4.01 \pm 0.56$ & $0.16 \pm 0.02$ \\
\cline { 2 - 5 } & Coefficient of variation (\%) & 20.28 & 13.97 & 12.5 \\
\hline \multirow{2}{*}{\begin{tabular}{c} 
Taxus chinensis - stem \\
\cline { 2 - 5 }
\end{tabular}} & Average Value \pm Standard Deviation & $68.38 \pm 19.08 \mathrm{c}$ & $4.60 \pm 0.36$ & $0.07 \pm 0.01$ \\
\hline
\end{tabular}




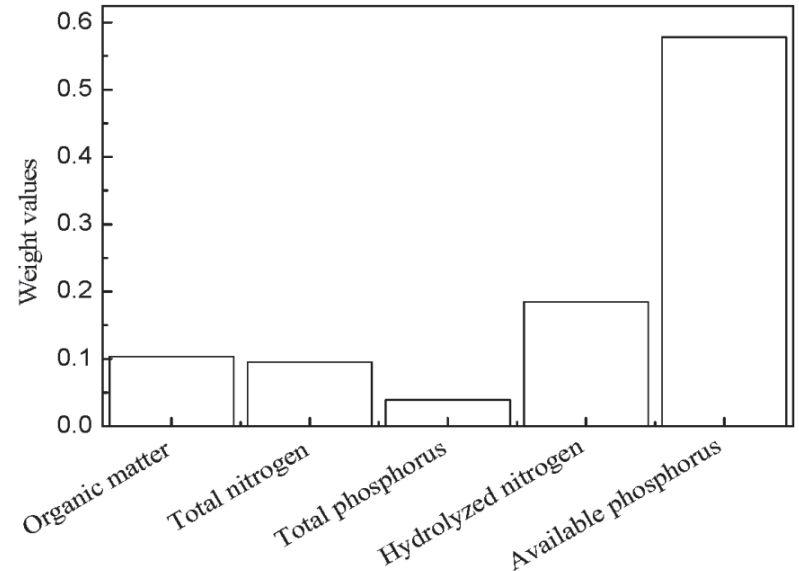

Physical and chemical indexes of soil

Fig. 2. Weight values calculated by the weighted average method.

\section{Analysis of Correlation between Taxus wallichiana and Soil Nutrients}

Table 5 exhibits the resultof correlation analysis of C: N: P in the leaf of Taxus wallichiana and contents of other indexes ( $\mathrm{C}, \mathrm{N}, \mathrm{P}$ and other nutrient elements) in the soil. The $\mathrm{C} / \mathrm{N}$ in the leaf of Taxus wallichiana is significantly positively correlated with soil organic carbon, TN, TP, TK, C/N, and N/P. However, its weak influence on hydrolysable-N, valid-P, and valid-K, indicates that soil TN, TP, and TK might affect its $\mathrm{C} / \mathrm{N}$ through influencing the absorption of $\mathrm{C}$ or the conversion of $\mathrm{N}$ in the leaf of Taxus wallichiana. The $\mathrm{C} / \mathrm{P}$ in the leaf of Taxus wallichiana is significantly positively correlated with the $\mathrm{C} / \mathrm{P}$ in the soil. It is also extremely negatively correlated with Hydrolysable-N in the soil, and significantly negatively correlated with $\mathrm{N} / \mathrm{P}$ in the soil. The results indicated that the content of hydrolysable-N in the soil might affect Taxus wallichiana absorbing $\mathrm{C}$ or $\mathrm{P}$. The $\mathrm{N} / \mathrm{P}$ in the leaf of Taxus wallichiana was extremely significantly and positively correlated with $\mathrm{TN}, \mathrm{TK}, \mathrm{C} / \mathrm{P}$ in the soil. It is significantly positively correlated with the organic carbon and $\mathrm{C} / \mathrm{N}$ in the soil and significantly negatively correlated with valid-P contents in the soil. The satiation exhibits that the leaf of Taxus wallichiana absorbing $\mathrm{N} / \mathrm{P}$ is largely affected by the content of total-K in the soil apart from the influence of $\mathrm{N}$ and $\mathrm{P}$ contents in the soil. Based on the above analysis, it is obtained that $\mathrm{C}$, $\mathrm{N}$, and $\mathrm{P}$ contents in the leaf of Taxus wallichiana were significantly affected by $\mathrm{N}, \mathrm{P}, \mathrm{K}$ and organic carbon in the soil.
Fig. 3 shows the correlation analysis result of $\mathrm{C}$ : $\mathrm{N}$ : $\mathrm{P}$ in the stem of Taxus wallichiana and $\mathrm{C}, \mathrm{N}, \mathrm{P}$ and other nutrient elements in the soil. The value of N/P in the stem of Taxus wallichiana is significantly positively correlated with total $\mathrm{P}$ and negatively correlated with $\mathrm{C} / \mathrm{P}$ and $\mathrm{N} / \mathrm{P}$ in soil. Additionally, the total $\mathrm{P}$ is significantly negatively correlated with $\mathrm{N} / \mathrm{P}$ and $\mathrm{C} / \mathrm{P}$ in soil. The total $\mathrm{K}$ is significantly positively and negatively correlated with organic matter and hydrolysable $\mathrm{N}$ in soil, respectively. Interestingly, $\mathrm{C} / \mathrm{P}$ is significantly positively correlated with $\mathrm{N} / \mathrm{P}$ in soil. It shows that $\mathrm{C} / \mathrm{P}$ of Taxus wallichiana, apart from affecting by $\mathrm{C} / \mathrm{P}$ in the soil, is also greatly affected by and positively corrected with $\mathrm{TN}, \mathrm{TP}$, and $\mathrm{TK}$ in the soil. In summary, the contents of TN, TP and TK in the soil might remarkably affect the absorption and solidification of the stem of Taxus wallichiana on P. Relationships of $\mathrm{C}, \mathrm{N}$ and $\mathrm{P}$ in the stem of Taxus wallichiana and physical-chemical indexes of soil.

Fig. 4 demonstrates the two-dimensional sorting diagram of $\mathrm{C}, \mathrm{N}$ and $\mathrm{P}$ in the stem of Taxus wallichiana and soil environmental factors. $\mathrm{C}$ and $\mathrm{N}$ are significantly negatively correlated in the stem of Taxus wallichiana. The contents of $\mathrm{C}, \mathrm{N}$ and $\mathrm{P}$ are affected at different degrees by different soil environmental factors. Specifically, the concentrations of $\mathrm{C}$ and $\mathrm{N}$ in the stem are primarily affected by these factors, such as soil bulk density, $\mathrm{Na}$ and $\mathrm{Ca}$, rather than $\mathrm{Mg}$, $\mathrm{TP}$, and $\mathrm{TN}$. Meanwhile, $\mathrm{P}$ in the stem and $\mathrm{TP}, \mathrm{Cu}$, valid-P and $\mathrm{Mg}$ in the soil are greatly correlated, while nearly unrelated to $\mathrm{C}$ and $\mathrm{Zn}$ in the soil. The order of influence degree of various environmental factors on $\mathrm{N}$ in the stem is $\mathrm{Ca}>\mathrm{Na}>$ soil bulk density ( $\mathrm{SBD})>\mathrm{Zn}>\mathrm{Fe}>$ valid-K $>$ valid- $\mathrm{P}>\mathrm{TK}>\mathrm{pH}>\mathrm{TN}>\mathrm{SOC}>\mathrm{Mn}>\mathrm{Mg}>$ Hydrolysable-N $>$ $\mathrm{Cu}>\mathrm{TP}$. The order of influence degree on $\mathrm{P}$ in the stem is valid-P $>\mathrm{TP}>\mathrm{Cu}>\mathrm{Mg}>\mathrm{SOC}>\mathrm{TN}>$ hydrolysable$\mathrm{N}>\mathrm{TK}>\mathrm{Mn}>\mathrm{pH}>\mathrm{Fe}>$ valid $-\mathrm{K}>\mathrm{SBD}>\mathrm{Zn}>\mathrm{Ca} \mathrm{Na}$.

Relationships of C, N, P in the Leaf of Taxus wallichiana and Physical-Chemical Indexes of Soil

Fig. 5 shows the two-dimensional sorting diagram of $\mathrm{C}, \mathrm{N}$, and $\mathrm{P}$ in the leaf of Taxus wallichiana and soil environmental factors. The contents of $\mathrm{C}$ and $\mathrm{N}$ are significantly negatively correlated in the leaf of Taxus wallichiana. $\mathrm{P}$ in the leaf is positively and negatively correlated with $\mathrm{P}$ and $\mathrm{N}$ in the leaf, respectively. Taking the correlation of $\mathrm{C}$ and $\mathrm{N}$ in the stem of Taxus wallichiana into account, the similar correlation of $\mathrm{C}$, $\mathrm{N}$ and $\mathrm{P}$ contents can be found in different parts of the same specie. In terms of correlation of the leaf $(C$, $\mathrm{N}$ and $\mathrm{P}$ ) and soil environmental factors, $\mathrm{C}$, and $\mathrm{N}$ in

Table 7. Comprehensive Fertility Index of soils around Taxus chinensis.

\begin{tabular}{|c|c|c|c|}
\hline Soil & Unweighted & Method of weighted mean & Soil fertility assessment \\
\hline Soil comprehensive fertility index & 14.75 & 4.917 & Very fertile \\
\hline
\end{tabular}




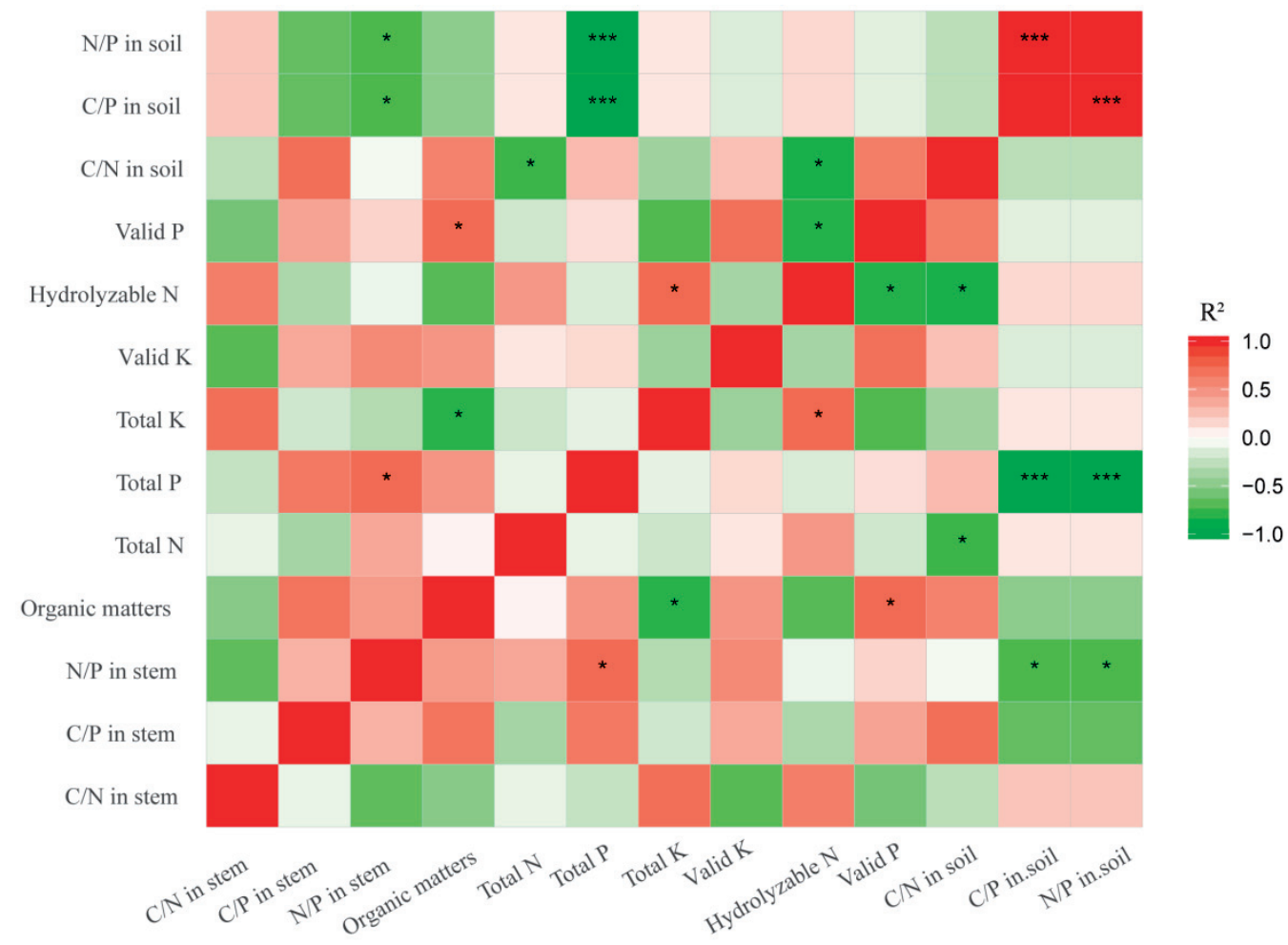

Fi. 3. Correlations between nutrients in Taxus chinensis- stem and soils. Annotation: *significant correlation at 0.05 level; **significant correlation at 0.01 level.

the leaf of Taxus wallichiana is primarily affected by factors such as soil bulk density, Zn, Valid-K. However, organic carbonwas hardly affected by $\mathrm{Mg}$ and $\mathrm{Cu}$ in the soil. $\mathrm{P}$ in the leaf of Taxus wallichiana is mainly subjected to TP, TK, TN, and soil bulk density in the soil

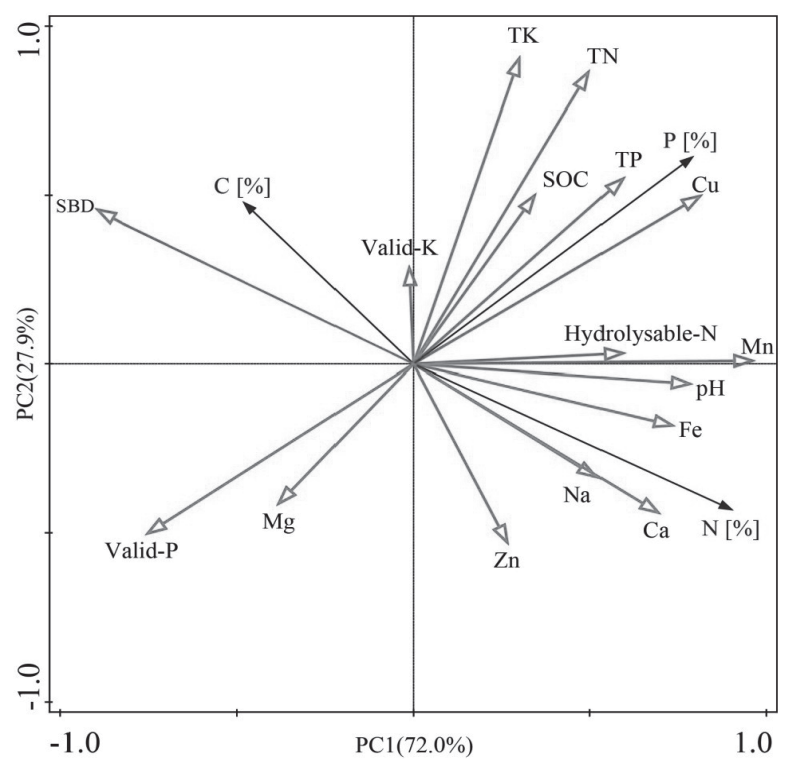

Fig. 4. Relationships of C, N, P in the stem of Taxus wallichiana var. mairei and physical-chemical indexes of soil. Annotation: TK is total K, TP is total P, TN is total N, SBD is soil bulk density. while being hardly affected by $\mathrm{Cu}$ content. Phosphorus in leaves of hydrolyzable- $\mathrm{N}$ in the soil. The order of influence degree of various environmental factors on $\mathrm{C}$ in the stem is $\mathrm{SBD}>\mathrm{Zn}>$ Valid $-\mathrm{K}>\mathrm{SOC}>\mathrm{Ca}>\mathrm{TP}>\mathrm{Na}$ $>$ hydrolysable $-\mathrm{N}>\mathrm{Fe}>\mathrm{TN}>\mathrm{TK}>\mathrm{pH}>$ valid $-\mathrm{P}>\mathrm{Mn}>$ $\mathrm{Cu}>\mathrm{Mg}$. The order of influence degree of various

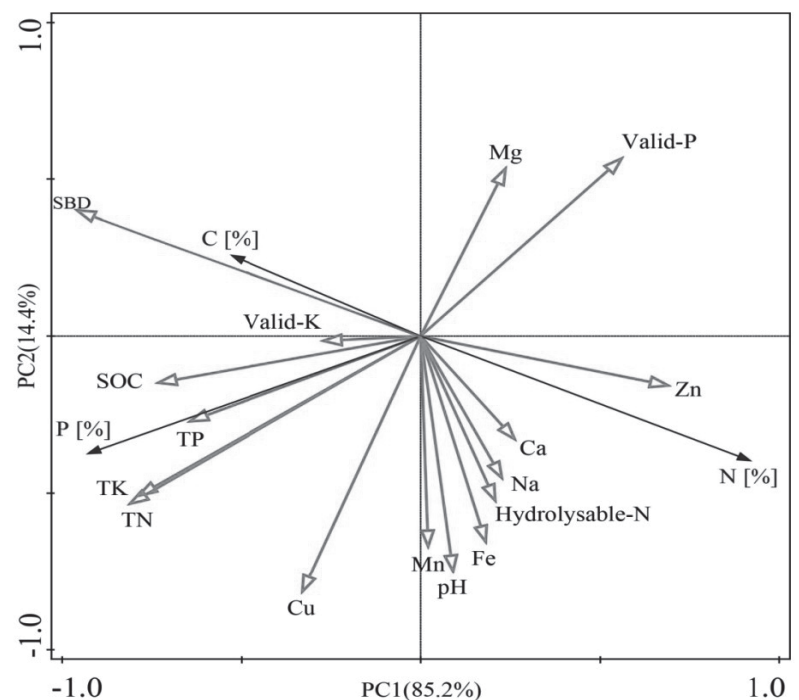

Fig. 5. Relationships of C, N, P in the leaf of Taxus wallichiana var. mairei and physical-chemical indexes of soil. Annotation: TK is total K, TP is total P, TN is total N, SBD is soil bulk density. 
environmental factors on $\mathrm{P}$ in the stem is $\mathrm{TP}>\mathrm{TN}>\mathrm{TK}>$ SOC $>$ valid- $\mathrm{P}>$ valid-K $>\mathrm{SBD}>\mathrm{Zn}>\mathrm{Cu}>\mathrm{Mg}>\mathrm{Ca}>\mathrm{Mn}>\mathrm{pH}$ $>\mathrm{Fe}>\mathrm{Na}>$ hydrolyze $\mathrm{N}$.

\section{Discussion}

\section{Characteristics of Differences in C, N, and P Contents in Soil Surrounding Taxus wallichiana}

Generally, the stoichiometric characteristic of plants and soils is conducive to discover the laws of nutrient migration at different parts of the biogeochemical cycle. The method also can clarify the stability of ecosystems and the limitation of plant nutrients, and put forward strategies for plants to adapt to the environment [2327]. A wide range of soil quality evaluation methods including the soil quality comprehensive scoring method, the soil quality dynamics method, and the soil quality multi-variable index method have been proposed by many researches [28]. Notably, the effective, reliable, sensitive, repeatable and acceptable indicators should be determined before selecting the evaluation method for establishing a framework system of comprehensive evaluation of soil quality. Meanwhile, the correlation analysis method, the method of weighted average, and the coefficient of variation method were applied for comprehensively evaluating the soil fertility of paddy fields and dry lands. The evaluation result can objectively and accurately reflect the soil fertility, which can provide a reference support for understanding the soil fertility status of Mount Fanjing and dry lands [29]. The combined effect of the interaction among evaluation index weights, index membership values, and indicators on soil fertility was considered in this study and a soil fertility evaluation model was developed.

According to the results from weighted value combining the improved Nemerow index method analysis, the contents of organic matters, TN, TP, hydrolyzable-N, and valid-P were abundant in the soils surrounding the Taxus wallichiana trees in comparison with the $2^{\text {nd }}$ national soil survey [30]. Nevertheless, the difference and applicability of weights with varied methods should be further studied.

\section{Comparison of Stoichiometric Ratio C: N: P in the Soil and Plant}

The ratio of $\mathrm{C}: \mathrm{N}$ : $\mathrm{P}$ in plants can reflect some information of soil nutrient status. In this study, the $\mathrm{C}$ content in the leaf of Taxus wallichiana was $458.30 \mathrm{mg} / \mathrm{g}$, which was slightly greater than the global average $\mathrm{C}$ content in leaves $(464 \mathrm{mg} / \mathrm{g}$ ) [31]. Moreover, C: P is also a factor affecting the growth rate of plants. In general, a low $\mathrm{C}$ : $\mathrm{P}$ indicates an increase in the distribution of $\mathrm{P}$ in rRNA for meeting the needs of supporting the rapid growth of plants with ribosome's rapid synthesis of proteins [32]. The $\mathrm{C}: \mathrm{N}$ and $\mathrm{C}: \mathrm{P}$ in the plant leaf presented its ability of assimilating $\mathrm{C}$ and absorbing nutrients. They reflect the utilization efficiency of plant nutrients and represent the efficiency of $\mathrm{C}$ fixation in different plants. $\mathrm{C}$ : $\mathrm{N}$ reflected the effectiveness of soil organic matter used by microorganisms [33].

In this study, $\mathrm{C}$ : $\mathrm{N}$ in the soil of Taxus wallichiana wood was consistent with the average ratio of the land soil in China with a small coefficient of variation. C: N, $\mathrm{C}$ : $\mathrm{P}$ and $\mathrm{N}$ : $\mathrm{P}$ in the soil of this study were $11.61 \pm 1.12$, $21.90 \pm 2.12$, and $1.89 \pm 0.51$, respectively. Compared with the average level of China's terrestrial soil (C: N, C: P and $\mathrm{N}: \mathrm{P}$ are 11.9, 61.0 and 5.2, respectively), $\mathrm{C}: \mathrm{N}$ in the soil in this study is not significantly different from the average level. However, ratios C: P and N: P were below the average level, which may be due to the low $\mathrm{P}$ background value in the subtropical red soil area. C: $\mathrm{P}$ and N: P in the soil of the Taxus wallichiana wood in Mount Fanjing were varied significantly. The small spatial distribution of $\mathrm{C}$ : $\mathrm{N}$ can be found in different climatic zones, soil types, weathering degrees and soil layer factors. Therefore, a large spatial heterogeneity exists in $\mathrm{C}$ : $\mathrm{P}$ and $\mathrm{N}$ : $\mathrm{P}$. Internal $\mathrm{C}$ and $\mathrm{N}$ are no longer changed with plant metabolic activities upon the apoptosis of plant organs. Besides, $\mathrm{C} / \mathrm{N}$ in the soil were mostly originated from the decomposition of plant residues. Plant residues can accessed to the soil for maintaining the stability of $\mathrm{C}: \mathrm{N}$ since decomposed plants are decomposed by microorganisms with a strict observation of the stoichiometric ratio [34].

Influences of Environmental Factors on C, N and $\mathrm{P}$ in the Leaf and Stem of Taxus wallichiana

Environmental factors (such as $\mathrm{SBD}, \mathrm{Zn}$, valid-K, SOC, Ca, TP, Na, hydrolysable-N, Fe, TN, TK, pH, valid-P, $\mathrm{Mn}, \mathrm{Cu}$ and $\mathrm{Mg}$ ) have effects on the content distribution in the leaf and stem of Taxus wallichiana. Based on the analysis, $\mathrm{Ca}$ has the greatest effect on the $\mathrm{N}$ distribution in the stem of Taxus wallichiana. This element is one of the most abundant elements in the soils, playing a special role among essential elements in plants. It acts as a structural material of the cell and also as a second messenger to regulate the plant to respond to environmental changes. Changes in environmental factors can lead to the increased free $\mathrm{Ca}$ activity in the cytoplasm. Hence, the activity of protein kinases in the body can be changed to induce the expression of related genes, or to regulate the activity of enzymes [35]. High free $\mathrm{Ca}$ in the cytoplasm is detrimental to plant growth. This may be caused by affecting plant growth through forming precipitates with $\mathrm{P}$, interfering with the process related to $\mathrm{P}$ metabolism, or obstructing normal signal transmission. Therefore, cytoplasmic free $\mathrm{Ca}$ concentration can be increased rapidly in response to environmental changes while maintaining a low concentration underground state condition.

Moreover, valid-P had the greatest effect on $\mathrm{P}$ distribution in the stem of Taxus wallichiana. A large amount of $\mathrm{P}$ is a must for the growth and development 
of plants. P required for plant growth and development is mainly acquired from soil $\mathrm{P}$, or absorbing sufficient $\mathrm{P}$ through fertilization. $\mathrm{P}$ deficiency exerts an influence on plant photosynthesis, respiration and biosynthesis. $\mathrm{P}$ deficiency in plants might be resulted from low utilization of $\mathrm{P}$, which rendered that the plant cannot be developed in a healthy way. When the TP content of the soil is less than $0.03 \%$, valid-P deficiency can be detected in the soil. Soil valid-P is an indicator of evaluating the level of $\mathrm{P}$ nutrient supply in the soil. The $\mathrm{P}$ content in the soil can reflect the storage and supply capacity of $\mathrm{P}$ in the soil to some extent. Adjusting soil $\mathrm{pH}$ and increasing soil organic matter are effective ways of improving $\mathrm{P}$ in the soil.

SBD is the most influential factor of $\mathrm{C}$ content in the leaf of Taxus wallichiana. It is a critical basic data that affects crop growth. Small SBD value indicates that the porous and well-structured soil is suitable for crop growth [36]. In contrast, large SBD indicates that the compact and hard soil with the lack of granular structure exerts an adverse effect on crop growth. TP in the soil has the greatest impact on the $\mathrm{P}$ content in the plant. A great deal of $\mathrm{P}$ is required for plant growth and development. $\mathrm{P}$ required for plant growth and development is mainly acquired from the soil phosphorus pool, or absorbing sufficient $\mathrm{P}$ through fertilization. $\mathrm{P}$ deficiency exerts an influence on plant photosynthesis, respiration and biosynthesis. $\mathrm{P}$ deficiency in plants might be resulted from low utilization of $\mathrm{P}$, so that the plant cannot be developed in a healthy way.

\section{Conclusion}

The abundant contents of organic matters, TN, TP, hydrolyzable-N, and valid-P were found in the soils surrounding the Taxus wallichiana tress in comparison with the $2^{\text {nd }}$ national soil survey. The soil of this study area was fertile according to the evaluation of weighted value combining the improved Nemerow index method. Ratios of $\mathrm{C}$ : N, C: P and N: P in the soilswas considered as $11.61 \pm 1.12,21.90 \pm 2.12$, and $1.89 \pm 0.51$, respectively. The coefficient of variation of $\mathrm{N} / \mathrm{P}$ in the soil is the largest. Ca has the greatest impact on the distribution of $\mathrm{N}$ in the stem of Taxus wallichiana. The valid-P exerts the greatest influence on the distribution of $\mathrm{P}$ in the stem of Taxus wallichiana. The SBD is the largest influencing factor of the C content in the leaf of Taxus wallichiana. The Total-P in the soil has a dominant influence on the $\mathrm{P}$ content in the plant.

\section{Acknowledgments}

This work was financially supported by the Guizhou science and technology support plan project (No. [2020] 1Y178, [2019] 2840, [2019] 1217, [2017] 1176); the basic condition platform construction project of Guizhou science and Technology Department [2019] 5701.

\section{Conflict of Interest}

The authors declare no conflict of interest.

\section{References}

1. GHOLAMHOSEIN IM., AGHAALIKHANI M., MALAKOUTI M.J., JOGHANA.K. Influence of zeolite application on nitrogen efficiency and loss in canola production under sandy soils conditions. Commun. Soil Sci. Plant Anal. 43 (9), 1247, 2012.

2. HALOI N., SARMA H.P. Heavy metal contaminations in the groundwater of Brahmap-utra flood plain, an assessment of water quality in Barpeta District, Assam (India). Environ. Monit. Assess. 184 (10), 6232, 2012.

3. LI C., XIONG K.N., WU G.M. Process of biodiversity research of karst areas in China. Acta Ecologica Sinica. 33 (4), 192, 2013.

4. NOUR H.E., EL-SOROGY A., ABDEL-WAHA B M., ALMADANI S., ALFAIFI H., YOUSSEF, M.Assessment of sediment quality using different pollution indicators and statistical analyses, Hurghada area, Red Sea coast, Egypt. Mar. Pollut. Bull. 133, 8010, 2018.

5. SUN W.L., SANG L.X., JIANG B.F. Trace metals in sediments and aquatic plants from the Xiangjiang River, China. J. Soil. Sediment. 12, 1652, 2012.

6. LU X., TODA H., DING F., FANG S.Z., YANG W.X., XU H.G. Effect of vegetationtypes on chemical and biological properties of soils of karst ecosystems. Eur. J. Soil Biol. 61, 52, 2014.

7. CAO S., DUAN X., ZHAO X., CHEN Y., WANG B., SUN C., ZHENG B., WEI F. Health risks of children's cumulative and aggregative exposure to metals and metalloids in a ty-pical urban environment in China. Chemosphere. 147, 406, 2016.

8. TAYLOR T., GOODNOE J.P., HILL K.A. Effects of variation in carbon, nitrogen, and p-hosphorus molarity and stoichiometry on sex determination in the fern ceratopterisrichardii. Botanique. 94 (4), 249, 2016.

9. CHEN G., CHEN Y., ZHAO G., CHENG W., GUO S., ZHANG H., SHI W. Do high nitrogenuse efficiency rice cultivars reduce nitrogen losses from paddy fields? Agr. Ecosyst. Environ. 209, 27, 2015.

10. SHI Y.Z., RUAN J.Y., MA L.F., HAN W.Y., WAN GF. Accumulation and distribution of arsenic and cadmiumby tea plants. Journal of Zhejiang University-Science B. 9 (3), $265,2008$.

11. YOUSSEF M., EL-SOROGY A. Environmental assessment of heavy metal contamination in bottom sediments of Al-Kharrar lagoon, Rabigh, Red Sea, Saudi Arabia. Arab.J. Geosci. 9 (6), 475, 2016.

12. ZHENG H., SU Y.R., HE X.Y., HU L.N., WU J.S., HUANG D.Y., LI L., ZHAO C.X.Modified method for estimating organic carbon density of discontinuous soil in peak-karst regions in Southwest China. Environmental Earth Sciences. 67 (6), 1743, 2012.

13. XIAO Q., ZONG Y.T., LU S.G.Assessment of heavy metal pollution and human health risk in urban soils of steel industrial city (Anshan), Liaoning, Northeast 
China. Ecotoxic-ology and environmintal safety. 120, 378, 2015.

14. RASHID N., BASRA S.M.A. SHAHBAZ M., IQBAL S., HAFEEZ M.B.Foliar applied mori-nga leaf extract induces terminal heat tolerance in quinoa. Intl. J. Agric. Biol. 20, $158,2018$.

15. ZHANG J.T., RU W.M. Population characteristics of endangered species Taxus chinensisvar. maireiand its conservation strategy in Shanxi, China. Population Ecology. 52, 290, 2010.

16. ZHANG D.Q., ZHOU N. Genetic diversity and population structure of the endangered conifer Taxus wallichiana var. mairei (Taxaceae) revealed by Simple Sequence Repeat (SSR) markers. Biochem. Syst. Ecol. 28, 721, 2013.

17. ZHANG R. Genetic Diversity and Genetic Differentiation of Taxus wallichianavar. mairei Provenances. Scientia Silvae Sinicae. 45, 50, 2009.

18. ZHOU A.I., CHEN W.W. LIAO L. XIE P.C. Comparative adsorption of emerging contaminants in water by functional designed magnetic poly ( $\mathrm{N}$-isopropylacrylamide)/chitosan hydrogels. Sci. Total Environ. 671, 379, 2019.

19. WU T.G., CHEN B.F., XIAO Y.H., PAN Y.J., CHEN Y., XIAO J.H. Leaf stoichiometry of trees in three forest types in Pearl River Delta, South China. Chinese Journal of Plant Ecology. 34, 59, 2010.

20. LV Y.N., XIONG K.N., RONG L.,XU H., GAO Y.,YING B. Comparative analysis of world heritage values on biological and ecologicalevolution in Fanjingshan Mountain. World Regional Studies. 25 (5), 132, 2016 [In Chinese].

21. HE G.D., ZHANG Z.M., ZHANG J.C., HUANG X.F. Stoichiometric characteristics of nutrients in a soilvegetation system of the rare plant Davidia involucrata Baill. Global Ecology and Conservation. 24, e01266, 2020.

22. WEN S.H., PAN Z.B., XU H. Comprehensive Evaluation of Soil Fertility Quality of Alfalfa Field in the Dryland of Loess Hilly Region in Southern Ningxia. Research of Soil and Water Conservation. 22, 57, 2014 [In Chinese].

23. BAKIS R., TUNCAN A.An investigation of heavy metal and migration through groun-dwater from the landfill area of Eskisehir in Turkey.Environ.Monit.Assess. 176, 89, 2011.

24. FAN H.M., XU M.X., LI B.B., ZHANG R.R., ZHANG S.M., MA L.Y. Influence of soil physical properties on salt content in soil profile of farmland in WeiBei region.J.Soil Water Conserv. 4, 199, 2017.

25. GUTTIERI M.J., BAENZIGER S.P., FRELS K., CARVER B., ARNALL B., WANG S. Prospects for selecting wheat with increased zinc and decreased cadmium concentration in grain. Cr-op Sci. 55, 1713, 2015.
26. NAMAGHI H.H., KARAMI G.H., SAADAT S. A study on chemical properties of groundwater and soil in ophiolitic rocks in Firuzabad, east of Shahrood, Iran, with emphasis to heavy metal contamination. Environ. Monit. Assess. 174, 575, 2011.

27. LUO S.J., HE Y.H., NING G.G., ZHANG J.Q., MA G.Y., BAO M.Z. Genetic diversity and genetic structure of different populations of the endangered species Davidiainvolucrata in China detected by inter-simple sequence repeat analysis. Trees. 25 (6), 1064, 2011

28. LI Y.C., LI Y.F., CHANG S.X., YANG Y.F., FU S.L., JIANG P.K., LUO Y., YANG M., CHEN Z.H., HU S.D., ZHAO M.X., LIANG X., XU Q.F., ZHOU G.M., ZHOU J.Z. Biochar reduces soil heterotrophic respiration in a subtropical plantation through increasing soil organic carbon recalcitrancy and decreasing carbon-degrading microbial activity. Soil Biology and Biochemistry. 122, 176, 2018

29. QIU L.F., YANG C., LIN F.F., YANG N., ZHENG X.Y., XU H.W., WANG K. Spatial pattern of soil fertility in Bashan tea garden:A prediction based on environmentalauxiliary variables. Chinese Journal of Applied Ecology. 21 (12), 3100, 2010 [In Chinese].

30. HU W.J., CHEN J., LIU T.W., SIMON M., WANG W.H., CHEN J., WU F.H., LIU X., SHEN Z.J., ZHENG H.L. Comparative Proteomic Analysis of Differential Responses of P-inusmassoniana and Taxus wallichiana var. mairei to Simulated Acid Rain. Int. J. Mol. Sci. 15 (3), 4334, 2014.

31. WANG X., HUANG X., HU J., ZHANG Z. The Spatial Distribution Characteristics of Soil Organic Carbon and Its Eects on Topsoil under Dierent Karst Landforms.Int. J. Environ. Res. Public Health. 17, 2889, 2020.

32. NIU X., GAO P., LI Y.X., LI X. Impact of different afforestation systems on soilorganic carbon distribution characteristics of limestone mountains. Pol. J.Environ. Stud. 24 (6), 2543, 2015.

33. YANG H., ZHANG P., ZHU T., LI Q., CAO J. The characteristics of soil $\mathrm{C}, \mathrm{N}$, and $\mathrm{P}$ stoichiometric ratios asa_ected by geological background in a karst graben area, southwest China.Forests. 10 (7), 601, 2019.

34. LI Y.C., YANG J., ZHOU X.R., ZHAO W., JIAN Z.Y. Isolation and Identification of a 10-Deacetyl Baccatin-IIIProducing Endophyte from Taxus wallichiana. Applied Biochemis-try and Biotechnology. 175, 2224, 2015.

35. WANG C.W., PENGS.L., LIM.G., LI W.J., LIN F.L. Review of factors affecting the taxoids content of Taxus spp. ActaEcologicaSinica.26 (5), 1583, 2006 [In Chinese].

36. HE Y., LI T.X., WANG Y.D. Soil fertility in tea plantations in different slope positions and elevation regions.Chinese Journal of Eco-Agriculture. 17 (4), 661, 2009. 